\title{
Pengaruh Intensitas Pengungkapan Dimensi Sustainability Reporting Terhadap Reaksi Pasar Perusahaan BUMN Yang Terdaftar Di BEI
}

\author{
Made Linda Lestari ${ }^{1}$ \\ Ketut Alit Suardana ${ }^{2}$ \\ ${ }^{1,2}$ Fakultas Ekonomi dan Bisnis Universitas Udayana (Unud), Bali, Indonesia \\ e-mail: madelinda97@gmail.com
}

\begin{abstract}
ABSTRAK
Penelitian ini bertujuan untuk mendapatkan bukti empiris guna mengonfirmasi pengaruh intensitas pengungkapan dimensi sustainability reporting pada reaksi pasar perusahaan BUMN yang terdaftar di BEI. Penelitian dilakukan pada perusahaan BUMN yang terdaftar di BEI tahun 2013-2017. Penentuan sampel penelitian menggunakan teknik purposive sampling. Terdapat 7 perusahaan sebagai sampel dengan total sebanyak 35 observasian. Proses pengumpulan data dilakukan melalui metode dokumentasi. Teknik analisis data yang digunakan yaitu uji regresi linear berganda. Berdasarkan hasil analisis, ditemukan bahwa hanya intensitas pengungkapan dimensi lingkungan yang berpengaruh positif signifikan terhadap kinerja perusahaan yang diproksikan dengan nilai earnings per share perusahaan (EPS). Hasil ini memiliki arti bahwa semakin banyak indikator lingkungan yang diungkapkan oleh perusahaan dalam sustainability reporting maka akan semakin tinggi nilai EPS perusahaan tersebut. Sedangkan hasil analisis untuk dimensi ekonomi dan dimensi sosial menunjukan bahwa intensitas pengungkapan indikator ekonomi maupun indikator sosial pada sustainability reporting perusahaan tidak berpengaruh terhadap nilai EPS perusahaan.
\end{abstract}

Kata Kunci: Sustainability reporting, Dimensi ekonomi, dimensi lingkungan, dimensi Sosial, Earnings per Share.

\begin{abstract}
This study aims to obtain empirical evidence to confirmed the effect of intensity disclosure on each aspect of sustainability reporting in BUMN companies which are listed on Indonesia Stock Exchange by the year 2013 until 2017. Determination of sample through the purposive sampling technique. There are 7 companies are being used as samples with 35 observation objects. The data were collected by documentation method. This research was using multiple linear regression analysis. Based on the analyzes result, environmental aspect has positive effect on the performance of companies which is reflected by the value of earnings per share (EPS). This result has meaning that the more environmental indicators were disclosed, the value of EPS on those companies will be more increasing. Whereas the result for economics aspect and social aspect shows that the intensity disclosure on those two aspectson sustainability reporting have no effect for the value of EPS.

Keywords : Sustainability reporting, Economics Aspect, Environmental Aspect, Social Aspect, Earnings per Share.
\end{abstract}

\section{PENDAHULUAN}

Perkembangan praktik bisnis yang semakin pesat sering diikuti dengan eksploitasi sumber daya alam secara besar-besaran yang menjadi pemicu terjadinya 
kerusakan lingkungan. Isu kerusakan lingkungan merupakan salah satu dampak yang disebabkan oleh tingginya keberpihakan manajemen perusahaan kepada para shareholder. Untuk mengatasi isu tersebut, maka pihak perusahaan harus dapat merangkul seluruh stakeholder demi memperoleh keuntungan dalam jangka waktu yang panjang. Dalam hal ini, konsep sustainability merupakan salah satu cara untuk memperoleh keuntungan jangka panjang dalam persaingan bisnis.

Salah satu representasi dari konsep sustainability dalam suatu perusahaan dapat dilihat melalui laporan keberlanjutan atau yang dikenal dengan sebutan sustainability reporting. Pengungkapan tanggung jawab sosial perusahaan ini merupakan suatu publikasi informasi dalam suatu organisasi yang dapat menggambarkan bagaimana kinerja organisasi tersebut dalam dimensi ekonomi, sosial, dan lingkungan (ACCA, 2013). Publikasi informasi ini juga mengacu pada konsep sustainable development yang memiliki makna bahwa pembangunan yang berlangsung pada saat ini bisa terpenuhi tanpa harus mengurangi kemampuandari generasi mendatang untuk memenuhi kebutuhan mereka (Kates, et al, 2005). Konsep sustainable development perlu diterapkan dalam aktivitas ekonomi yang dewasa ini cenderung merusak ekosistem global dan menghambat kebutuhan generasi selanjutnya (Utama, 2011). Oleh karena itu, perlu adanya keterlibatan dari seluruh stakeholder baik secara individu dan kolektif untuk mencapai suatu keberlanjutan (Sudana, dkk, 2014).

Sustainability (keberlanjutan) adalah suatu keadaan dimana dapat tercapainya keseimbangan antara people-planet-profit, yang dikenal dengan konsep triple bottom line $(T B L)$. Elkington mengatakan bahwa perusahaan yang 
berkeinginan agar usahanya dapat berjalan secara berkelanjutan haruslah memerhatikan konsep triple bottom line tersebut. Selain mengejar suatu keuntungan (profit), perusahaan juga harus terlibat dalam berbagai aktivitas pemenuhan kesejahteraan masyarakat (people), dan juga ikut berkontribusi dalam menjaga kelestarian lingkungan (planet). Hal tersebut akan menjadi salah satu dasar bagi investor dalam memberikan suatu keputusan investasi.

Ketertarikan investor individual akan informasi sosial yang dilaporkan perusahaan dalam laporan tahunan mampu menegaskan bahwa keputusan investasi yang hanya berdasarkan informasi ekonomi sudah kurang relevan lagi, sehingga investor individual juga menggunakan informasi sosial dan lingkungan di dalam mengambil keputusan investasi.Publikasi sustainability reporting akan memberikan manfaat jangka panjang. Salah satu manfaat yang akan diperoleh bagi perusahaan yang telah menerapkan konsep sustainability dengan baik adalah mendapat citra positif dari masyarakat yang tentunya menjadi nilai tambah bagi perusahaan.

Hal ini menjadi faktor pendorong dalampeningkatan jumlah perusahaan yang melakukan pengungkapan sustainability report dari waktu ke waktu, baik tergabung dalam laporan tahunannya maupun diungkapkan secara terpisah dalam laporan sustainability reporting suatu perusahaan. Hal ini juga kemudian dapat dipertegas melalui hasil survei yang telah dilakukan oleh KPMG pada tahun 2016 dan menyatakan bahwa jumlah perusahaan yang melampirkan laporan yang terkait dengan aspek lingkungan dan sosial pada laporan keuangannya mulai mengalami peningkatan secara signifikan. Badan Usaha Milik Negara (BUMN) 
merupakan salah satu pelaku bisnis yang diwajibkan untuk melakukan berbagai kegiatan keberlanjutan yang dapat diungkapkan dalam suatu laporan perusahaan.

Dalam Peraturan Menteri BUMN No.9 Tahun 2015 Pasal 2 ayat 1 diatur bahwa dalam menjalankan kegiatan bisnisnya, Perum maupun Persero wajib untuk melaksanakan Program Kemitraan dan Bina Lingkungan (PKBL) dengan memenuhi ketentuan-ketentuan yang terdapat dalam peraturan tersebut. Peraturan Menteri BUMN tersebut mencerminkan keseriusan serta perhatian yang dimiliki oleh pemerintah terhadap aspek tanggung jawab sosial dan lingkungan di dalam dunia bisnis. Pengungkapan berbagai kegiatan keberlanjutan (sustainability activities) dalam suatu laporan keberlanjutan perusahaan terbukti berkorelasi positif terhadap kinerja keuangan suatu perusahaan (Braendle dan Mozghovyi, 2016). Pengungkapan sustainability reporting dapat meningkatkan kinerja keuangan pada sisi profitabilitas dan likuiditas perusahaan (Tarigan dan Semuel, 2016). Pengungkapan Sustainability Report (SR) yang dilakukan oleh perusahaan dapat dipandang sebagai suatu sinyal oleh investor dan calon investor. Para pelaku pasar modal akan mengevaluasi setiap pengumuman yang diterbitkan oleh emiten, sehingga hal tersebut akan memicu reaksi pasar (Hartono, 2016).

Teori sinyal menjelaskan bahwa laporan keuangan yang baik merupakan salah satu sinyal bahwa perusahaan juga beroperasi dengan baik (Ross, 1977). Dalam hal ini pihak manajemen perusahan memiliki kewajiban untuk memberikan sinyal mengenai kondisi perusahaan tersebut kepada para pemilik modal sebagai wujud tanggung jawab atas berbagai kegiatan pengelolaan perusahaan. Sinyal tersebut juga merupakan suatu informasi yang dapat menggambarkan kinerja 
manajemen perusahaan dalam rangka mewujudkan keinginan dari para pemilik modal (Nuswandari, 2009). Intensitas pengungkapan sustainability reporting dapat memberikan sinyal baik ataupun buruk kepada para pengguna informasi keuangan suatu perusahaan. Suatu perusahaan akan berusaha untuk mengungkapkan sebanyak-banyaknya indikator dalam sustainability reporting perusahaan untuk dapat menarik minat investor.

Reaksi pasar dalam intensitas pengungkapan laporan keberlanjutan suatu perusahaan akan dipengaruhi oleh perspektif stakeholders (Matten, et.al, 2003). Reaksi tersebut muncul karena perusahaan yang menggungkapkan sustainability reportingakan meningkatkan tingkat kepercayaan stakeholders, reaksi pasar ini dapat dilihat dari laba per lembar saham atau earnings per share. Penelitian Reddy dan Gordon (2010) menunjukkan bahwa sustainability reporting berpengaruh signifikan dalam menjelaskan peningkatan profitabilitas perusahaan di Australia. Pada aspek ekonomi pengungkapan tersebut sangatlah penting dalam menilai pertumbuhan perusahaan sehingga stakeholders internal maupun eksternal tertarik untuk berinvestasi (Okoye, et.al, 2013).

Penelitian yang dilakukan oleh Marwati dan Yulianti (2015) menunjukkan bahwa terdapat pengaruh antara intensitas pengungkapan sustainability reporting terhadap EPS, dimana semakin banyak melakukan aktivitas sosial dan mengungkapkannya pada sustainability reporting tersebut maka semakin tinggi pula nilai laba per lembar sahamnya. Nilai EPS mewakili jumlah penghasilan yang diperoleh suatu perusahaan dalam satu periode untuk setiap saham yang beredar, yang kemudian akan digunakan oleh perusahaan dalam menentukan 
jumlah dividen yang akan dibagikan. Berdasarkan pernyataan tersebut, pada penelitian ini melibatkan variabel reaksi pasar sebagai variabel terikat yang diproksikan dengan nilai EPS.

Praktik keberlanjutan merupakan elemen potensial untuk menciptakan nilai jangka panjang dari pemegang saham mana yang akan diuntungkan. Dalam hal ini, perusahaan diminta untuk mengembangkan dan mengungkapkan informasi yang mencerminkan kriteria yang diadopsi dalam hal keberlanjutan, dan informasi ini biasanya muncul dalam sustainability reporting perusahaan mereka. Laporan keberlanjutan tersebut merupakan elemen yang membedakan antara perusahaan yang memiliki indeks keberlanjutan dan yang tidak memenuhi persyaratan untuk pengungkapan informasi tentang keberlanjutan (Ching, et.al, 2017).

Berdasarkan latar belakang permasalahan diatas, maka penelitian ini dilakukan bertujuan untuk mendapatkan bukti empiris guna mengkonfirmasi pengaruh intensitas pengungkapan dimensisustainability reporting pada reaksi pasar perusahaan BUMN yang terdaftar di BEI. Penelitian ini diharapkan dapat memberikan bukti empiris untuk mengonfirmasi teori sinyal (signalling theory) maupun teori legitimasi (legitimacy theory) serta memberikan gambaran serta wawasan tentang praktik sustainability reporting pada perusahaan BUMN di Indonesia. Hasil dari penelitian ini juga diharapkan dapat memberikan informasi dan pertimbangan bagi para pemangku kepentingan (stakeholders) perusahaan akan pentingnya variabel intensitas pengungkapan pada sustainability reporting dalam memengaruhi reaksi pasar terhadap suatu perusahaan sehingga memberikan masukan dan sumbangan yang berguna bagi investor dalam mengambil keputusan 
investasi untuk menjadikan sustainability reporting yang dipublikasikan oleh perusahaan sebagai bahan pertimbangan dalam melakukan investasi.

Pengungkapan SR mampu menjadi sinyal kepada pihak investor maupun calon investor karena terdapat kepercayaan dari investor bahwa investasi yang dilakukan pada perusahaan yang berlandaskan keberlanjutan akan mampu memberikan nilai yang lebih baik dalam jangka panjang. Investor maupun calon investor pun nantinya akan tertarik untuk berinvestasi pada perusahaan tersebut. Reaksi pasar inilah yang diharapkan dapat memengaruhi profitabilitas perusahaan yang tercermin melalui nilai earnings per share (EPS) perusahaan.

Teori sinyal (signalling theory) menekankan bahwa perusahaan dapat meningkatkan profitabilitasnya dengan melibatkan laporan keberlanjutan (Maulana dan Yuyetta, 2014). Dalam hal ini, suatu informasi terkait suatu perusahaan yang dipublikasikan sebagai suatu pengumuman akan memberikan suatu sinyal bagi investor yang hendak melakukan suatu pengambilan keputusan investasi. Publikasi dari sustainability reporting ini dapat digunakan dalam peningkatkan motivasi perusahaan untuk dapat memperlihatkan sesuatu hal yang positif melalui laporannya tersebut, dengan demikian teori sinyal menjelaskan bahwa suatu perusahaan memiliki kecenderungan untuk memberikan informasi yang lebih lengkap guna dapat membangun reputasi yang akan terlihat lebih baik dibandingkan dengan perusahaan yang lainnya agar dapat menarik minat investor secara lebih optimal.

Teori legitimasi menyatakan bahwa suatu perusahaan akan terus berusaha untuk dapat memastikan bahwa perusahaan tersebut beroperasi dalam bingkai dan 
norma yang berlaku di masyarakat atau lingkungan dimana perusahaan tersebut beroperasi. Teori Legitimasi mendorong perusahaan untuk meyakinkan bahwa aktivitas dan kinerjanya dapat diterima oleh masyarakat (Ghozali, 2007). Laporan terkait aktivitas tanggung jawab sosial dan lingkungan perusahaan yang diungkapkan dalam sustainability reporting dapat digunakan oleh suatu perusahaan dalam membuktikan bahwa perusahaan tersebut telah menjalankan tanggung jawab sosial dan lingkungan perusahaan sesuai norma yang berlaku sehingga keberadaannya dapat diterima oleh masyarakat.

Legitimasi berfokus pada apakah sistem nilai suatu organisasi konsisten dengan sistem nilai yang ada pada masyarakat, dan apakah tujuan organisasi adalah untuk memenuhi harapan sosial (Bhattacharyya, 2015). Legitimasi adalah kondisi yang ada ketika sistem nilai suatu entitas adalah sejalan dengan sistem nilai dari sistem sosial yang lebih besar di mana entitas tersebut berada dan publikasi sustainability reporting merupakan salah satu upaya perusahaan dalam mengungkapkan aktivitas tanggung jawab sosial mereka (Bhattacharyya, 2015).

Berbagai aktivitas tanggung jawab sosial dan lingkungan perusahaan ini diharapkan sejalan dengan konsep pembangunan berkelanjutan. Pembangunan yang berkelanjutan perlu untuk diimplementasikan sesuai dengan agenda Green Economy yang telah disepakati pada KTT Bumi Rio+20 yang dilaksanakan di Rio da Jeneiro pada bulan juni 2012. Penelitian Sudana (2014) menyatakan bahwa menerapkan sustainable development bermanfaat untuk memperbaiki lingkungan alam, meningkatkan pembangunan, dan kualitas hidup masyarakat. Hal ini juga didukung dengan penelitian dari Drexhage dan Murphy (2010) yang menyatakan 
bahwa pembangunan berkelanjutan merupakan sebuah paradigma pembangunan yang bersifat visioner dimana pemerintah, stakeholders, dan masyarakat telah berkomitmen untuk bersama-sama menyukseskan agenda pembangunan berkelanjutan tersebut. Salah satu bentuk komitmen tersebut dari pihak perusahaan adalah melalui publikasi sustainability reporting yang bermanfaat dalam mencegah kekeliruan terhadap kebijakan akuntansi.

Penelitian Handoko dan Yuanita (2018) menunjukkan bahwa perusahaan yang melaporkan aktivitas tanggung jawab sosil dan lingkungan perusahaan dalam laporan keuangannya menandakan perusahaan tersebut sudah mulai menyadari bahwa kondisi keuangan saja tidak cukup menjamin suatu perusahaan dapat beroperasi secara berkelanjutan (sustainable). Keberlanjutan suatu perusahaan akan terjamin apabila perusahaan juga memerhatikan dimensi sosial dan lingkungan disamping memerhatikan dimensi ekonomi.

Sustainability reporting merupakan salah satu cara yang dilakukan perusahaan untuk menekankan kepada stakeholder terkait manajemen risiko dan informasi kinerja perusahaan (Ballou dan Heitger, 2005). Pengungkapan sustainability reporting yang dilakukan perusahaan adalah bentuk akuntabilitas dan transparansi kepada pihak stakeholder. Investor memiliki kecendrungan melakukan investasi pada perusahaan yang transparan karena kelengkapan dan keakuratan informasi akan dapat membantu investor dalam proses pengambilan keputusan investasinya (Ernst, et.al, 2013).

Salah satu perusahaan yang diwajibkan untuk melakukan dan mengungkapkan serta melampirkan laporan berbagai kegiatan tanggung jawab 
sosial dan lingkungan perusahaan diantaranya adalah perusahaan BUMN, yang dikenal dengan istilah program kemitraan bina lingkungan (PKBL) yang merupakan suatu strategi public relations (PR) dalam membentuk citra suatu perusahaan. PR dapat diwujudkan dalam berbagai kegiatan yang memiliki tujuan untuk memperoleh good will, kepercayaan, saling pengertian, guna menciptakan citra perusahaan yang baik dari publik serta menciptakan hubungan yang harmonis antara organisasi yang dalam penelitian ini antara perusahaan dengan karyawan maupun masyarakat melalui proses komunikasi.

Reaksi pasar terhadap peristiwa announcement/disclosure dapat dilihat dari adanya perubahan laba saham dan aktivitas volume perdagangan saham (Nurdin dan Cahyandito, 2006). Dalam penelitian ini, reaksi pasar diproksikan menggunakan perubahan laba per lembar saham (earnings per share). Earnings Per Share (EPS) merupakan suatu alat yang digunakan dalam menganalisis tingkat profitabilitas suatu perusahaan yang menggunakan konsep laba konvensional. EPS merupakan salah satu dari dua alat ukur yang sering digunakan untuk mengevaluasi saham biasa disamping PER (Price Earning Ratio). EPS menggambarkan tingkat keuntungan bersih untuk tiap lembar saham yang dapat diraih oleh suatu perusahaan pada saat menjalankan operasi perusahaannya. Salah satu hal yang menjadi alasan investor dalam membeli saham adalah memperoleh deviden, dalam hal ini apabila nilai laba per saham kecil maka kemungkinan perusahaan untuk membagikan deviden juga kecil. Dengan demikian dapat dikatakan bahwa investor akan cenderung lebih tertarik kepada saham yang 
memiliki nilai EPS yang tinggi dibandingkan dengan saham yang memiliki EPS rendah.

Dalam pelaksanaan berbagai program tanggung jawab sosial dan lingkungan tersebut tentunya juga diikuti dengan pembuatan laporan pertanggungjawaban yang berupa sustainability reporting yang dapat diungkapkan secara terpisah maupun tergabung dalam laporan tahunan perusahaan. Perusahaan BUMN yang sudah go public atau sahamnya diperdagangkan di bursa efek, maka akan berusaha sedemikian rupa untuk mengungkapkan seoptimal mungkin setiap aspek/indikator yang terdapat dalam sustainability reporting perusahaan. Hal ini salah satunya bertujuan untuk menarik minat investor dan juga calon investor.

Pengungkapan sustainability reporting tersebut menjadi sinyal positif dari perusahaan dalam meyakinkan seluruh stakeholders bahwa perusahaan memiliki kinerja yang baik dan juga memerhatikan aspek keberlanjutan dalam aktivitas bisnisnya, dengan harapan pasca pengungkapan sustainability reporting tersebut maka pasar akan bereaksi dan dapat dicerminkan oleh peningkatan nilai laba per lembar saham atau earnings per share (EPS) perusahaan.

Penelitian Nuswandari (2009) menyatakan bahwa semakin banyak suatu perusahaan mengungkapkan laporan mereka, maka semakin besar pula harapan perusahaan untuk mendapatkan sinyal positif dari para pemangku kepentingan. Namun Rodriguez-Fernandez (2016) mengatakan bahwa kebijakan terkait tangggung jawab sosial perusahaan berubah menjadi keuntungan yang lebih tinggi dan keuntungan yang lebih tinggi berubah menjadi kebijakan tanggung jawab sosial. Penelitian yang dilakukan oleh Wijaya (2017) menyatakan bahwa 
Made Linda Lestari dan Ketut Alit Suardana. Pengaruh ...

intensitas pengungkapan dalam sustainability reporting berpengaruh positif signifikan pada volume perdagangan saham perusahaan. Hal ini memiliki makna bahwa intensitas pengungkapan dalam sustainability reporting mampu mempengaruhi keputusan investor secara individual. Intensitas pengungkapan dalam sustainability reporting direaksi secara signifikan oleh pasar dalam bentuk volume perdagangan saham yang nantinya akan beraksi kepada earnings per share sebagai tanggapan atas sinyal positif yang diberikan perusahaan melalui pengungkapan sustainability reporting.

Laba per lembar saham atau earnings per share (EPS) mewakili jumlah penghasilan yang didapatkan oleh perusahaan dalam satu periode untuk setiap saham yang beredar, yang kemudian akan digunakan oleh perusahaan dalam menentukan jumlah dividen yang akan dibagikan. Perusahaan yang memberikan kontribusi besar dalam peningkatan ekonomi mikro maupun makro akan menarik minat investor untuk berinvestasi dalam perusahaan tersebut. Cahyandito dalam Natalia (2014) menyatakan bahwa pengungkapan kinerja ekonomi dalam sustainability reporting akan merangsang peningkatan kepercayaan stakeholder dan investor yang kemudian akan meningkatkan citra perusahaan dan juga kinerja keuangan suatu perusahaan. Dengan demikian, semakin banyak indikator kinerja ekonomi yang diungkapan dalam sustainability reporting tersebut, maka akan semakin dapat meningkatkan kepercayaan para stakeholder dan investor.

$\mathrm{H}_{1}$ : Intensitas Pengungkapan Kinerja Ekonomi dalam Sustainability Reporting berpengaruh positif dan signifikan terhadap reaksi pasar.

Semakin baik kinerja lingkungan perusahaan maka akan semakin baik pula kinerja keuangannya karena perolehan pendapatan dan efisiensi biaya yang akan 
mendorong profitabilitas perusahaan. Informasi yang tercantum dalam laporan keberlanjutan dimensi lingkungan dapat meyakinkan stakeholder bahwa potensi sumber daya modal perusahaan bersifat kompetitif dan memiliki tingkat resiko rendah (Tarigan \& Semuel, 2016). Hal ini menunjukkan bahwa dalam menjalankan aktivitas bisnisnya, perusahaan juga tetap memerhatikan lingkungan sekitarnya. Semakin banyak indikator yang diungkapkan dalam sustainability reporting terkait dengan kinerja lingkungan, maka akan semakin menarik minat investor untuk berinvestasi yang nantinya akan ditunjukkan oleh reaksi pasar terhadap perusahaan tersebut.

$\mathrm{H}_{2}$ : Intensitas Pengungkapan Kinerja Lingkungan dalam Sustainability Reporting berpengaruh positif dan signifikan terhadap reaksi pasar.

Dengan melaksanakan dan menungkapkan aktivitas tanggung jawab sosial suatu perusahaan pada sustainability reporting, maka akan memicu reaksi pasar yang ditunjukkan dari meningkatkan harga saham rata-rata perusahaan (Ernst, et.al, 2013). Penelitian yang dilakukan oleh N. Burhan \& Rahmanti (2015) juga menemukan bahwa pengungkapan kinerja sosial berdampak positif terhadap kinerja keuangan yang merupakan wujud reaksi pasar terhadap pengungkapan tersebut. Perusahaan yang banyak mengungkapan indikator kinerja sosial pada sustainability reportingnya maka akan semakin dapat meyakinkan investor bahwa kegiatan bisnis mereka tetap memerhatikan aspek sosial dengan baik.

$\mathrm{H}_{3}$ : Intensitas Pengungkapan Kinerja Lingkungan dalam Sustainability Reporting berpengaruh positif dan signifikan terhadap reaksi pasar. 


\section{METODE PENELITIAN}

Penelitian ini dilakukan di Bursa Efek Indonesia dengan mengakses website www.idx.co.id. Dan website masing-masing perusahaan BUMN. Objek penelitian ini adalah intensitas pengungkapan sustainability reporting dan reaksi pasar pada perusahaan BUMN yang terdaftar di Bursa Efek Indonesia. Adapun Variabel terikat dalam penelitian ini adalah reaksi pasar yang diproksikan dengan EPS. Variabel bebas yang digunakan dalam penelitian ini adalah intensitas pengungkapan kinerja dimensi ekonomi, lingkungan, dan sosial dalam sustainability reporting yang diukur dengan indeks SRDI.

Populasi yang digunakan dalam penelitian ini meliputi seluruh perusahaan BUMN yang terdaftar di Bursa Efek Indonesia selama periode 2013-2017. Penentuan sampel penelitian dilakukan melalui metode non probability sampling dengan menggunakan teknik purposive sampling sehingga diperoleh 7 perusahaan BUMN yang memenuhi kriteria tertentu. Adapun kriteria yang digunakan dalam menentukan sampel penelitian diantaranya adalah perusahaan BUMN yang sudah go public serta mempublikasikan laporan tahunan (annual report) dan juga melakukan pengungkapan sustainability reporting secara terpisah selama periode 2013-2017.

Data yang digunakan dalam penelitian ini adalah data kuantitatif yang terdiri dari intensitas pengungkapan dalam sustainability reporting dan nilai earnings per share (EPS) yang diambil dari laporan tahunan (annual report) perusahaan BUMN yang terdaftar di Bursa Efek Indonesia tahun 2013-2017. Sumber data dalam penelitian ini adalah data sekunder eksternal yang dikumpulkan dengan 
metode dokumentasi. Teknik analisis data yang digunakan terbagi ke dalam beberapa tahap yaitu analisis statistik deskriptif, uji asumsi klasik, analisis regresi linear berganda, uji koefisien determinasi $\left(\mathrm{R}^{2}\right)$, uji kelayakan model (uji F), dan uji hipotesis (Uji t).

\section{HASIL DAN PEMBAHASAN}

Analisis statistik deskriptif data penelitian yang berhubungan dengan pengumpulan dan peringkat data yang menggambarkan karakteristik dari sampel yang digunakan dalam suatu penelitian. Analisis ini berguna dalam menjelaskan karateristik dari sampel yang meliputi nilai mean, nilai ekstrim, dan standar deviasi dari tiap-tiap variabel. Hasil dari statistik deskriptif disajikan pada Tabel 1.

Tabel 1.

Hasil Statistik Deskriptif Variabel Penelitian

\begin{tabular}{llrrrr}
\hline & N & \multicolumn{1}{c}{ Min } & \multicolumn{1}{c}{ Mean } & \multicolumn{1}{c}{ Max } & \multicolumn{1}{c}{ Std. Deviation } \\
\hline SRDI Dimensi Ekonomi (X1) & 35 & .111 & .889 & .51746 & .210375 \\
SRDI Dimensi Lingkungan (X2) & 35 & .029 & .676 & .23866 & .152623 \\
SRDI Dimensi Sosial (X3) & 35 & .063 & .750 & .30417 & .172700 \\
Earnings Per Share (Y) & 35 & .006 & 1071.509 & 385.41594 & 344.467299 \\
Valid N (listwise) & 35 & & & & \\
\hline
\end{tabular}
Sumber: Data diolah, 2018

Nilai minimum dari reaksi pasar adalah 0,006dan nilai maksimumnya adalah 1071,509 Nilai rata-rata (mean) untuk reaksi pasar adalah 385,415. Mean dari reaksi pasar yang bernilai positif, memiliki arti bahwa rata-rata pasar bereaksi terhadap intensitas pengungkapan dimensi sustainability reporting yang dilakukan oleh perusahaan BUMN. Deviasi standar adalah 344,467. Nilai standar deviasi reaksi pasar yang lebih kecil dari pada nilai rata-rata (mean) memiliki arti bahwa terdapat fluktuasi yang rendah pada reaksi pasar terhadap perusahaan BUMN yang menjadi sampel. 
Nilai minimum dari variabel intensitas pengungkapan kinerja dimensi ekonomi adalah 0,111 dan nilai maksimumnya sebesar 0,889. Mean atau nilai rata-rata intensitas pengungkapan kinerja dimensi ekonomi adalah 0,517. Nilai rata-rata yang lebih mendekati nilai maksimum ini memiliki arti bahwa rata-rata intensitas pengungkapan kinerja dimensi ekonomi perusahaan BUMN cenderung tinggi. Rata-rata perusahaan BUMN memiliki intensitas pengungkapan dimensi ekonomi sebesar 51,7 persen. Standar deviasi sebesar 0,210, lebih besar daripada nilai rata-rata dan hal tersebut berarti fluktuasi intensitas pengungkapan kinerja dimensi ekonomi pada perusahaan BUMN terbilang tinggi.

Nilai minimum intensitas pengungkapan kinerja dimensi lingkungan adalah 0,029. Nilai maksimumnya adalah 0,676. Mean atau nilai rata-rata dari intensitas pengungkapan kinerja dimensi lingkungan adalah 0,238 atau rata-rata perusahaan BUMN memiliki intensitas pengungkapan dimensi ekonomi sebesar 23,8 persen. Standar deviasinya adalah 0,152 , lebih kecil dari pada nilai rata-rata. Hal tersebut berarti terdapat fluktuasi yang rendah pada intensitas pengungkapan kinerja dimensi lingkungan dalam sustainability reporting.

Nilai minimum intensitas pengungkapan kinerja dimensi sosial adalah 0,063. Nilai maksimumnya adalah 0,750. Mean atau nilai rata-rata dari intensitas pengungkapan kinerja dimensi lingkungan adalah 0,304 atau 30,4 persen. Standar deviasinya adalah 0,172 , lebih kecil dari pada nilai rata-rata.Hal tersebut memiliki arti bahwa terdapat fluktuasi yang rendah pada intensitas pengungkapan kinerja dimensi sosial dalam sustainability reporting. 
Analisis data yang digunakan dalam penelitian ini adalah analisis regresi linier berganda. Analisis regresi digunakan untuk mengetahui pengaruh variabelvariabel yang diteliti. Sebelum dilakukan analisis regresi, maka terlebih dahulu dilakukan uji asumsi klasik atas model yang digunakan (Sugiyono, 2017). Uji asumsi klasik diperlukan agar model regresi yang dijadikan alat estimasi tidak bias. Uji asumsi klasik dalam penelitian ini terdiri dari uji normalitas, uji autokorelasi, uji multikolonieritas, dan uji heteroskedastisitas. Uji normalitas ini digunakan untuk mengetahui apakah variabel pengganggu dari sebuah model regresi berdistribusi normal atau tidak. Penelitian ini menggunakan KolmogorovSmirnov testdalam melakukan uji normalitas. Hasil dari uji normalitas dalam penelitian ini disajikan dalam Tabel 2.

Tabel 2.

Hasil Uji Normalitas

\begin{tabular}{lll}
\hline & Unstandardized Residual & \\
\hline $\mathrm{N}$ & & 35
\end{tabular}

Asymp. Sig. (2-tailed) Sumber: Data diolah, 2018

Berdasarkan Tabel 2, nilai dari Asymp. Sig. (2-tailed)yang dimiliki pleh model persamaan yang diuji sebesar 0,200 atau lebih besar dari 0,05. Hal ini menunjukkan bahwa data yang digunakan dalam penelitian ini telah berdistribusi normal.

Uji autokorelasi bertujuan untuk menguji apakah dalam model regresi linear ada korelasi antara kesalahan pengganggu pada periode $\mathrm{t}$ dengan kesalahan pengganggu pada periode t-1 (Ghozali, 2016: 107). Apabila suatu model regresi mengandung gejala autokorelasi, maka prediksi yang dilakukan dengan 
menggunakan model regresi tersebut menjadi tidak baik atau bahkan dapat memberikan hasil prediksi yang tidak sesuai atau menyimpang.

Tabel 3.

Hasil Uji Autokorelasi

\begin{tabular}{lrrrrr}
\hline Model & R & R Square & $\begin{array}{c}\text { Adjusted R } \\
\text { Square }\end{array}$ & $\begin{array}{c}\text { Std. Error of the } \\
\text { Estimate }\end{array}$ & Durbin-Watson \\
\hline 1 & $.476^{\mathrm{a}}$ & .226 & .152 & 3.31886 & 1.680 \\
\hline Sumber:Data diolah, 2018 & & & &
\end{tabular}

Hasil pengujian autokorelasi menunjukkan nilai dw yang dihasilkan sebesar 1,680. Oleh karena jumlah $\mathrm{n}=35$ dan $\mathrm{k}=3$, diperoleh nilai $\mathrm{d}_{\mathrm{L}}$ sebesar 1,283 dan $\mathrm{d}_{\mathrm{u}}$ sebesar 1,653 sehingga diperoleh nilai 4 - $\mathrm{d}_{\mathrm{u}}$ sebesar 2,347, maka dapat dirumuskan kriteria $\mathrm{d}_{\mathrm{u}}<\mathrm{dw}<4-\mathrm{d}_{\mathrm{u}}$ yaitu $1,653<1,680<2,347$. Hal ini menunjukkan data yang digunakan pada penelitian ini bebas dari autokorelasi.

Uji multikolonieritas bertujuan untuk menguji apakah model regresi ditemukan adanya korelasi antar variabel bebas, karena model regresi yang baik seharusnya tidak terjadi korelasi antara variabel bebas. Adapun hasil pengujian multikolonieritas disajikan pada Tabel 4.

Tabel 4.

\section{Hasil Uji Multikolonieritas}

\begin{tabular}{lcc}
\hline \multicolumn{1}{c}{ Variabel } & \multicolumn{2}{c}{ Collinearity Statistics } \\
\cline { 2 - 3 } & Tolerance & VIF \\
\hline SRDI Dimensi Ekonomi (X1) & .408 & 2.452 \\
SRDI Dimensi Lingkungan (X2) & .745 & 1.342 \\
SRDI Dimensi Sosial (X3) & .406 & 2.466 \\
\hline Sumber: Data diolah, 2018 & \multicolumn{2}{c}{}
\end{tabular}

Berdasarkan hasil uji multikolonieritas pada Tabel 4, SRDI Dimensi Ekonomi (X1), SRDI Dimensi Lingkungan (X2), dan SRDI Dimensi Sosial (X3) menunjukkan nilai tolerance $>0,1$ atau nilai $\mathrm{VIF}<10$. Oleh karena itu, dapat disimpulkan bahwa variabel bebas dalam penelitian ini terbebas dari multikolonieritas atau tidak ada korelasi antar variabel bebas. 
Uji Heteroskedastisitas bertujuan menguji apakah dalam model regresi terjadi ketidaksamaan variance dari residual satu pengamatan ke pangamatan yang lain. Suatu model regresi yang mengandung gejala heteroskedastisitas dapat memberikan hasil prediksi yang menyimpang. Adapun hasil pengujian heteroskedastisitas disajikan pada Tabel 5.

Tabel 5.

Hasil Uji Heterokedastisitas

\begin{tabular}{lcc}
\hline \multicolumn{1}{c}{ Variabel } & Sig. & Keterangan \\
\hline SRDI Dimensi Ekonomi (X1) & .978 & Bebas Heteroskedastisitas \\
SRDI Dimensi Lingkungan (X2) & .817 & Bebas Heteroskedastisitas \\
SRDI Dimensi Sosial (X3) & .853 & Bebas Heteroskedastisitas \\
Sumber: Data diolah, 2018 & &
\end{tabular}

Berdasarkan hasil uji heteroskedastisitas pada Tabel 5, diketahui nilai signifikansi variabel SRDI Dimensi Ekonomi, SRDI Dimensi Lingkungan, dan SRDI Dimensi Sosial terhadap variabel absolut residual berada diatas 0,05 maka dapat disimpulkan bahwa data yang digunakan pada penelitian ini tidak terdapat masalah heteroskedastisitas.

Penelitian ini menggunakan persamaan regresi linear berganda untuk mengetahui SRDI Dimensi Ekonomi, SRDI Dimensi Lingkungan, dan SRDI Dimensi Sosial terhadap earnings per share.Rekapitulasi hasil analisis regresi linear berganda disajikan pada Tabel 6 . 
Tabel 6.

Rekapitulasi Hasil Regresi Linear Berganda

\begin{tabular}{|c|c|c|c|c|c|}
\hline \multirow[t]{2}{*}{ Variabel } & \multicolumn{2}{|c|}{$\begin{array}{l}\text { Unstandardized } \\
\text { Coefficients }\end{array}$} & \multirow{2}{*}{$\begin{array}{c}\begin{array}{c}\text { Standardized } \\
\text { Coefficients }\end{array} \\
\text { Beta }\end{array}$} & \multirow[t]{2}{*}{$\mathrm{t}$} & \multirow[t]{2}{*}{ Sig. } \\
\hline & $\mathrm{B}$ & Std. Error & & & \\
\hline (Constant) & 193.464 & 139.678 & & 1.385 & .176 \\
\hline SRDI Dimensi Ekonomi (X1) & 328.015 & 384.756 & .200 & .853 & .400 \\
\hline SRDI Dimensi Lingkungan (X2) & 1301.095 & 392.324 & .576 & 3.316 & .002 \\
\hline SRDI Dimensi Sosial (X3) & -947.822 & 469.982 & -.475 & -2.017 & .052 \\
\hline Adjusted $\mathrm{R}^{2}$ & & & 0,234 & & \\
\hline F-hitung & & & 4,470 & & \\
\hline Sig. F & & & 0,010 & & \\
\hline
\end{tabular}

Sumber: Data diolah, 2018

Berdasarkan informasi pada Tabel 6, maka dapat dibuat persamaan regresi seperti berikut ini.

$$
\begin{aligned}
\text { EPS }= & 193,464+328,015 \text { SRDI Ekonomi }+1.301,095 \text { SRDI Lingkungan }- \\
& 947,822 \text { SRDI Sosial }+\mathrm{e}
\end{aligned}
$$

Berdasarkan persamaan regresi maka dapat dijelaskan beberapa hal diantaranya adalah nilai konstanta 193,464 menunjukkan bahwa apabila intensitas pengungkapan sustainability reporting dimensi ekonomi, lingkungan, dan sosial sama dengan nol, maka nilai earnings per share sebesar Rp193,464. Nilai koefisien regresi intensitas pengungkapan sustainability reporting dimensi ekonomi (X1) sebesar 328,015 menunjukkan bahwa bila intensitas pengungkapan sustainability reporting dimensi ekonomi naik satu satuan, maka earnings per share akan mengalami peningkatan sebesar Rp 328,015 dengan asumsi variabel lainnya konstan.

Nilai koefisien regresi intensitas pengungkapan sustainability reporting dimensi lingkungan (X2) sebesar 1.301,095 menunjukan bahwa bila intensitas pengungkapan sustainability reporting dimensi lingkungan naik satu satuan, maka earnings per share akan mengalami peningkatan sebesar Rp 1.301,095 dengan 
asumsi variabel lainnya konstan. Nilai koefisien regresi intensitas pengungkapan sustainability reporting dimensi sosial (X3) sebesar -947,822 menunjukan bahwa bila intensitas pengungkapan sustainability reporting dimensi sosial naik satu satuan, maka earnings per share akan mengalami penurunan sebesar Rp 947,822 dengan asumsi variabel lainnya konstan.

Analisis koefisien determinasi digunakan untuk mengukur seberapa jauh kemampuan semua variabel bebas dalam menerangkan variasi dari variabel dependennya (Ghozali, 2016:95). Koefisien determinasi dalam penelitian ini dilihat dari adjusted R squareyaitu sebesar 0,234. Artinya 23,4 persen variasi perubahan earnings per share dapat dijelaskan oleh variabel intensitas pengugkapan sustainability reporting dimensi ekonomi, dimensi lingkungan, dan dimensi sosial. Sedangkan sisanya sebesar 76,6 persen variabel EPSdipengaruhi oleh variabel lain diluar model regresi yang digunakan.

Uji kelayakan model (Uji F) dalam suatu penelitian dilakukan untuk menguji kelayakan suatu model sebagai alat analisis dalam menguji pengaruh variabel independen pada variabel dependen dalam suatu penelitian. Adapun hasil pengujian kelayakan model menunjukkan bahwa nilai uji $\mathrm{F}$ sebesar 4,470 dengan p-value (Sig. F) 0,010 lebih kecil dari nilai $\alpha=0,05$. Dengan demikian, dapat dikatakan bahwa model persamaan dalam penelitian ini layak untuk digunakan.

Uji statistik t dilakukan untuk mengetahui seberapa besar pengaruh variabel bebas terhadap variabel terikatnya secara parsial. Pengujian ini dilakukan dengan cara melakukan perbandingan antara hasil nilai probabilitas ( $p$-value) tiap-tiap variabel dengan $\alpha=0,05$ seperti ditunjukkan pada Tabel 7 . 
Tabel 7.

Hasil Uji Hipotesis (Uji t)

\begin{tabular}{|c|c|c|c|c|c|}
\hline \multirow[t]{2}{*}{ Variabel } & \multicolumn{2}{|c|}{$\begin{array}{l}\text { Unstandardized } \\
\text { Coefficients }\end{array}$} & \multirow{2}{*}{$\begin{array}{c}\text { Standardized } \\
\text { Coefficients }\end{array}$} & \multirow[t]{2}{*}{$\mathrm{t}$} & \multirow[t]{2}{*}{ Sig. } \\
\hline & $\mathrm{B}$ & Std. Error & & & \\
\hline (Constant) & 193.464 & 139.678 & & 1.385 & .176 \\
\hline SRDI Dimensi Ekonomi (X1) & 328.015 & 384.756 & 200 & .853 & .400 \\
\hline SRDI Dimensi Lingkungan (X2) & 1301.095 & 392.324 & .576 & 3.316 & .002 \\
\hline SRDI Dimensi Sosial (X3) & -947.822 & 469.982 & -.475 & -2.017 & .052 \\
\hline
\end{tabular}

Nilai signifikansi uji t yakni $p$-value sebesar 0,400 lebih besar dari $\alpha=0,05$ serta nilai koefisien regresi sebesar 328,015. Ini berarti bahwa intensitas pengungkapan dimensi ekonomi dalam sustainability reporting tidak berpengaruh terhadap earnings per share, sehingga hipotesis pertama tidak didukung.

Nilai signifikansi uji t yakni $p$-value sebesar 0,002 lebih kecil dari $\alpha=0,05$ serta nilai koefisien regresi sebesar 1.301,095. Ini berarti bahwa intensitas pengungkapan dimensi lingkungan berpengaruh positif signifikan terhadap earnings per share, sehingga hipotesis kedua dalam penelitian ini diterima

Nilai signifikansi uji t yakni $p$-value sebesar 0,052 lebih besar dari $\alpha=0,05$ serta nilai koefisien regresi sebesar -947,882. Ini berarti bahwa intensitas pengungkapan dimensi sosial dalam sustainability reporting tidak berpengaruh terhadap earnings per share, sehingga hipotesis ketiga tidak didukung.

Hasil analisis menunjukkan bahwa intensitas pengungkapan sustainability reporting dimensi ekonomi tidak berpengaruh terhadap reaksi pasar. Hasil ini tidak sesuai dengan hipotesis yang menyatakan bahwa intensitas pengungkapan sustainability reporting dimensi ekonomi berpengaruh positif signifikan terhadap reaksi pasar yang diproksikan oleh EPS. Hal ini dikonfirmasi oleh hasil penelitian dari Rita Wijayanti (2016) dan Anazonwu (2018) yang menyatakan bahwa 
intensitas pengungkapan sustainability reporting salah satunya pada dimensi ekonomi, tidak berpengaruh terhadap reaksi pasar. Hal ini menunjukkan kinerja keuangan yang baik pada kondisi saat ini di Indonesia, masih dapat dicapai oleh perusahaan kendatipun menempatkan aspek sustainability pada prioritas kedua atau ketiga. Seperti yang diungkapkan oleh Djajadikerta dalam Tarigan (2016) bahwa kesadaran dan pemahaman tentang sustainability reporting di Indonesia masih sangat kurang. Para pemangku kepentingan masih belum memerhatikan elemen-elemen yang dilaporkan dalam sustainability reporting sebagai suatu hal yang dapat dipertimbangkan dalam berbagai pengambilan keputusan perusahaan.

Intensitas pengungkapan dalam sustainability reporting yang tidak berpengaruh terhadap reaksi pasar ini juga salah satunya disebabkan karena adanya mixed persepsi seperti yang diungkapkan oleh Wijaya (2017). Mixed persepsi tersebut disebabkan oleh perbedaan pandangan antara investor yang memiliki pandangan investasi jangka panjang dengan investor yang memiliki pandangan jangka pendek sehingga tidak semua investor yang ada di pasar mampu menggunakan informasi yang terkandung dalam sustainability reporting.

Hasil analisis menunjukkan bahwa intensitas pengungkapan sustainability reporting dimensi lingkungan berpengaruh positif signifikan terhadap reaksi pasar. Hasil inisesuai dengan hipotesis yang menyatakan bahwa intensitas pengungkapan sustainability reporting dimensi lingkungan berpengaruh positif signifikan terhadap reaksi pasar. Semakin banyak indikator yang diungkapkan dalam sustainability reporting pada aspek lingkungannya maka akan semakin tinggi earnings per share yang dimiliki oleh suatu perusahaan. Perusahaan yang 
menerapkan konsep keberlanjutan dalam usahanya dan mengungkapkannya dalam sustainability reporting perusahaan, memiliki risiko bisnis yang lebih kecil karena dalam usahanya untuk memperoleh laba, perusahaan tetap mampu memerhatikan kondisi lingkungan sehingga tujuan usaha yang berlangsung secara berkelanjutan dapat tercapai.

Hasil penelitian ini sejalan dengan Amacha \& Dastane (2017), Nugroho dan Eko (2011), Wijayanti (2016), dan Ong (2016) yang menyatakan bahwa intensitas pengungkapan sustainability reporting salah satunya pada dimensi lingkungan berpengaruh positif signifikan terhadap nilai EPS perusahaan yang menunjukkan tingkat profitabilitas suatu perusahaan dari perspektif pemegang saham. Namun dilain sisi, hasil penelitian ini berlawanan dengan Anazonwu (2018) yang membuktikan intensitas pengungkapan pada sustainability reporting tidak berpengaruh terhadap earnings per share suatu perusahaan. Hasil yang berbeda kemungkinan disebabkan oleh adanya perbedaan perusahaan yang diteliti ataupun jumlah sampel yang digunakan.

Implikasi praktis dari hasil penelitian ini bagi investor dalam mengambil keputusan dalam berinvestasi, sebaiknya tidak hanya melihat aspek keuangan dari suatu perusahaan saja. Namun juga tetap melihat aspek non keuangan seperti aspek lingkungan yang juga diungkapkan dalam sustainability reporting suatu perusahaan. Implikasi teoritis hasil penelitian mendukung teori sinyal dan juga teori legitimasi. Semakin banyak indikator yang diungkapkan dalam sustainability reporting pada aspek lingkungannya memberikan sinyal kepada investor bahwa perusahaan sudah menjalankan bisnis nya secara sehat dengan tetap memerhatikan 
lingkungan sekitar tempat perusahaannya beroperasi. Perusahaan melakukan ini melalui perangkat legitimasi, biasanya laporan tahunan. Teori sinyal membantu kita memahami bahwa perusahaan biasanya melaporkan atau mengungkapkan informasi positif tentang kegiatan mereka untuk menunjukkan kinerja mereka di atas orang lain (Shehata, 2014). Oleh karena itu, teori legitimasi menunjukkan bahwa ketika perusahaan mengungkapkan informasi tentang pembangunan berkelanjutan, ini meningkatkan reputasi mereka yang pada gilirannya akan menarik anggota masyarakat.

Hasil analisis menunjukkan bahwa intensitas pengungkapan sustainability reporting dimensi sosial tidak berpengaruh terhadap reaksi pasar. Hasil ini tidak sesuai dengan hipotesis yang menyatakan bahwa intensitas pengungkapan sustainability reporting dimensi sosial berpengaruh positif signifikan terhadap reaksi pasar. Hasil penelitian ini sejalan dengan Wijayanti (2016), dan Anazonwu (2018) yang menyatakan bahwa intensitas pengungkapan sustainability reporting pada dimensi sosial tidak berpengaruh terhadapnilai EPS. Intensitas pengungkapan dalam sustainability reporting (SR) tidak diapresiasi oleh para investor secara keseluruhan sehingga tidak mampu mempengaruhi laba per lembar saham perusahaan. Praktik pengungkapan SR di Indonesia masih tergolong baru dan jumlah perusahaan yang mengungkapkan SR masih sangat sedikit, sehingga para investor secara umum memandang SR masih belum mampu membawa dampak yang signifikan jika dimasukan kedalam pertimbangan untuk melakukan investasi. 


\section{SIMPULAN}

Berdasarkan hasil analisis data dan pembahasan, maka kesimpulan yang dapat diberikan adalah intensitas pengungkapan kinerja dimensi lingkungan dalam sustainability reporting berpengaruh posititf signifikan terhadap reaksi pasar. Hal ini berarti bahwa jumlah indikator dimensi lingkungan yang diungkapkan oleh suatu perusahaan dalam sustainability reporting perusahaannya berhasil memengaruhi investor melalui nilai earning per share perusahaan. Semakin banyak indikator dalam dimensi lingkungan yang diungkapkan maka akan semakin besar nilai dari laba per lembar saham perusahaan tersebut. Sedangkan intensitas pengungkapan kinerja dimensi ekonomi dan sosial dalam sustainability reporting tidak berpengaruh terhadap reaksi pasar.

Hasil penelitian menunjukan intensitas pengungkapan masing-masing dimensi dalam sustainability reporting dengan reaksi pasar yang diproksikan dengan EPS menunjukan hasil yang signifikan pada dimensi lingkungan. Tanggung jawab perusahaan kepada lingkungan dan masyarakat yang diwujudkan dalam bentuk sustainability reporting ini harus tetap dijalankan, tidak hanya melibatkan laporan keberlanjutan saja, namun keikutsertaan perusahaan dalam berbagai ajang seperti ISRA juga dapat dipertimbangkan sehingga nantinya sustainability reporting suatu perusahaan dapat meningkatkan kredibilitas perusahaan di mata publik. Perusahaan penerbit sustainability reporting disarankan untuk tetap mempertahankan berbagai aktivitas keberlanjutan yang mereka laksanakan secara kontinu, dan mengungkapkan berbagai pelaksanaan aktivitas keberlanjutan tersebut se-optimal mungkin pada sustainability reporting 
perusahaan, serta mengeluarakan laoran terkait secara berkala setiap periodenya di masing-masing website perusahaan untuk memudahkan akses bagi para investor maupun stakeholder yang berkepentingan.

Bagi penelitian selanjutnya yang melakukan kajian sejenis disarankan untuk menggunakan pengukuran dengan selang waktu yang lebih panjang, mengingat sustainability reporting dapat dikaitkan dengan strategi jangka panjang dari pihak perusahaan. Selain itu, penelitian selanjutnya juga diharapkan dapat mengembangkan penelitian ini berupa penelitian event study untuk melihat reaksi investor terhadap informasi yang ada dengan membandingkannya nilai EPS perusahaan beberapa hari sebelum dan sesudah terbitnya sustainability reporting.

\section{REFERENSI}

ACCA. (2013). The Business Benefits of Sustainability Reporting in Singapore. The Association of Chartered Certified Accountants (ACCA).

Amacha, E. B., \& Dastane, O. (2017). Sustainability Practices as Determinants of Financial Performance: A Case of Malaysian Corporations. The Journal of Asian Finance, Economics and Business, 4(2), 55-68.

Anazonwu, H. O., Egbunike, F. C., \& Gunardi, A. (2018). Corporate Board Diversity and Sustainability Reporting: A Study of Selected Listed Manufacturing Firms in Nigeria. Indonesian Journal of Sustainability Accounting and Management, 4(2), 136.

Ballou, B., \& Heitger, D. L. (2005). The Rise of Corporate Sustainability Reporting: A Rapidly-Growing Assurance Opportunity The Rise of Corporate Sustainability Reporting: A Rapidly-Growing Assurance Opportunity. Journal of Accountancy, 202(6), 65-74.

Bhattacharyya, A. (2015). Corporate Social and Environmental Responsibility in an Emerging Economy: Through the Lens of Legitimacy Theory. Australasian Accounting, Business and Finance Journal, 9(2), 79-92. 
Braendle, U., \& Mozghovyi, Y. (2016). Csr - More Than Corporate Storytelling. Journal of Governance and Regulation, 2(2), 44-50.

Ching, H. Y., Gerab, F., \& Toste, T. H. (2017). The Quality of Sustainability Reports and Corporate Financial Performance: Evidence From Brazilian Listed Companies. SAGE Open Journals, 1(9).

Drexhage, J., \& Murphy, D. (2010). Sustainable Development: From Brundtland to Rio 2012. International Institute for Sustainable Development.

Ernst \& Young, \& Boston College Centre for Corporate Citizenship. (2013). Value of sustainability reporting - A study by EY and Boston College Center for Corporate Citizenship. EYGM Limited.

Ghozali, Imam dan Anis Chairiri. (2007). Teori Akuntansi. Penerbit Universitas Diponegoro. Semarang.

Ghozali, P. D. H. Ima. (2016). Aplikasi Analisis Multivariete dengan program IBM SPSS 23. Penerbit Universitas Diponegoro. Semarang.

Handoko dan Yuanita. (2018). Effect on Value of Financial Performance Company with Corporate Social Responsibility Disclosure and as a Good Corporate Governance Moderating Variable . Jurnal Ilmiah Ekonomi Bisnis Universitas Gunadarma, 4(1), 1-15.

Hartono, J. (2016). Teori Portofolio dan Analisis Investasi. Penerbit BPFE. Yogyakarta.

Kates, R. W., Parris, T. M., \& Leiserowitz, A. A. (2005). What is sustainable development? Goals, indicators, values, and practice. Heldref Publication.

Marwati, C. P., \& Yulianti. (2015). Analisis Pengungkapan Sustainability Report pada Perusahaan Non-Keuangan Tahun 2009-2013. Jurnal Dinamika Akuntansi, 7(2), 167-181.

Matten, D., Crane, A., \& Chapple, W. (2003). Behind the Mask: Revealing the True Face of Corporate Citizenship. Journal of Business Ethics, 45(2), 109120.

Maulana, F., \& Yuyetta, E. N. A. (2014). Pengaruh Karakteristik Perusahaan Terhadap Pengungkapan Corporate Social Responsibility (CSR). Diponegoro Journal of Accounting, 3(2), 1-4.

N. Burhan, A. H., \& Rahmanti, W. (2015). the Impact of Sustainability Reporting on Company Performance. Journal of Economics, Business, and Accountancy Ventura, 15(2), 257. 
Natalia, R., \& Tarigan, J. (2014). Pengaruh Sustainability Reporting Terhadap Kinerja Keuangan Perushaan Publik Dari Sisi Profitability Ratio. Business Accounting Review, 2(1), 111-120.

Nugroho, B. Y., \& Eko, U. (2011). Board Characteristics and Earning Management. Journal of Administrative Science \& Organization, 18(1), 110 .

Nugroho, V. (2011). Pengaruh struktur kepemilikan dan komposisi dewan komisaris terhadap manajemen laba. Jurnal Akuntansi 1, 11(1), 415-430.

Nurdin, E., \& Cahyandito, M. F. (2006). Pengungkapan tema-tema sosial dan lingkungan dalam laporan tahunan perusahaan terhadap reaksi investor 1 . Jurnal KLH.

Nuswandari, C. (2009). Pengungkapan Pelaporan Keuangan dalam Perspektif Signalling Theory. Jurnal Ilmiah Kajian Akuntansi, 1(1), 48-57.

Okoye, P. V. C., Egbunike, F. C., \& Meduoye, O. M. (2013). Sustainability Reporting: A Paradigm for Stakeholder Conflict Management. International Business Research, 6(5), 157-167.

Ong, T. S., Tho, H. S., Goh, H. H., Thai, S. B., \& Teh, B. H. (2016). The relationship between environmental disclosures and financial performance of public listed companies in Malaysia. International Business Management, 10(4), 461-467.

Reddy, K., \& Gordon, L. W. (2010). The Effect of Sustainability Reporting on Financial Performance: An Empirical Study Using Listed Companies. Journal of Asia Entrepreneurship and Sustainability, 6(2), 19-42.

Rodriguez-Fernandez, M. (2016). Social responsibility and financial performance: The role of good corporate governance. BRQ Business Research Quarterly, 19(1), 137-151.

Ross, S. A. (1977). The Determination of Financial Structure: The IncentiveSignalling Approach. The Bell Journal of Economics, 1(8), 23-40.

Shehata, N. F. (2014). Theories and Determinants of Voluntary Disclosure. Accounting and Finance Research, 3(1), 18-26.

Sudana, I. P., Sukoharsono, E. G., Ludigdo, U., \& Irianto, G. (2014). A Philosophical Thought on Sustainability Accounting. Research Journal of Finance and Accounting, 5(9), 1-10. 
Sugiyono. (2017). Metode Penelitian Bisnis. Penerbit Alfabeta. Bandung.

Tarigan, J., \& Semuel, H. (2016). Pengungkapan Sustainability Report dan Kinerja Keuangan. Jurnal Akuntansi Dan Keuangan, 16(2), 88-101.

Utama, S. (2011). An evaluation of support infrastructures for corporate responsibility reporting in Indonesia. Asian Business and Management Journals, 10(3), 405-424.

Wijaya, M. S., \& Sudana, I. P. (2017). Pengaruh Sustainability Report Pada Reaksi Pasar Dengan Kinerja Keuangan Sebagai Variabel Kontrol. E-Jurnal Akuntansi Universitas Udayana. 21(1), 616-642.

Wijayanti, Rita. (2016). Pengaruh Pengungkapan Sustainability Report terhadap Kinerja Keuangan Perusahaan. Seminar Nasional dan $3^{\text {rd }}$ Call for Syariah Paper Accounting FEB UMS. 